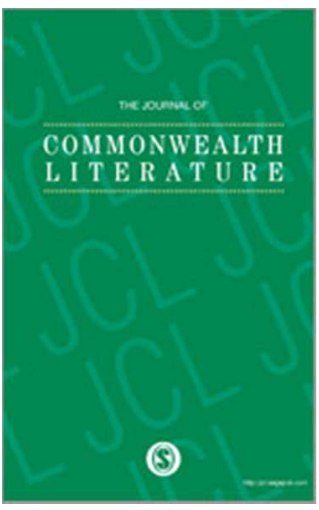

\title{
Post-9/11 Re-Orientalism: Confrontation and Conciliation in Mohsin Hamid's and Mira Nair's The Reluctant Fundamentalist
}

\begin{tabular}{|r|l|}
\hline Journal: & The Journal of Commonwealth Literature \\
\hline Manuscript ID & JCL-15-0068.R2 \\
\hline Manuscript Type: & Article \\
\hline Keywords: & $\begin{array}{l}\text { Mohsin Hamid, Mira Nair, The Reluctant Fundamentalist, re-orientalism, } \\
\text { film adaptation, Pakistan, 9/11 cinema, 9/11 literature, Islamophobia }\end{array}$ \\
\hline Abstract: & $\begin{array}{l}\text { This article offers a comparative reading of The Reluctant Fundamentalist, } \\
\text { the novel and the adaptation, looking at the ways these texts represent } \\
\text { changing Western public perceptions towards Pakistan and vice-versa } \\
\text { along the temporal axis 2001-2007-2012. Both novel and film are } \\
\text { informed by the post-9/11 distrust of the Muslim other. Mohsin Hamid's } \\
\text { novel was begun before } 9 / 11 \text { and published seven years later, in 2007; } \\
\text { Mira Nair's film adaptation followed in 2012, with a premiere at the Venice } \\
\text { Film Festival (as the opening film) and the Toronto Film Festival. Ostensibly } \\
\text { more conciliatory than Hamid's novel, Nair's film adaptation attempts to } \\
\text { build bridges, stressing the tragedy of cultural suspicion and mistrust that } \\
\text { besets the relationships between Pakistan and the US, endeavouring to } \\
\text { open and facilitate dialogue. Despite utilizing spaces of ambiguity to } \\
\text { expose the dangers of binary thinking, both novel and film ultimately } \\
\text { demonstrate that representations are still unable to escape the loop of } \\
\text { orientalism and re-orientalism, highlighting the tension of how East and } \\
\text { West continue as locked into this circular mode of relational identity. }\end{array}$ \\
\hline
\end{tabular}


Post-9/11 Re-Orientalism: Confrontation and Conciliation in Mohsin Hamid's and Mira Nair's The Reluctant Fundamentalist

\begin{abstract}
This article offers a comparative reading of The Reluctant Fundamentalist, the novel and the adaptation, looking at the ways these texts represent changing Western public perceptions towards Pakistan and vice-versa along the temporal axis 2001-2007-2012. Both novel and film are informed by the post-9/11 distrust of the Muslim other. Mohsin Hamid's novel was begun before 9/11 and published seven years later, in 2007; Mira Nair's film adaptation followed in 2012, with a premiere at the Venice Film Festival (as the opening film) and the Toronto Film Festival. Ostensibly more conciliatory than Hamid's novel, Nair's film adaptation attempts to build bridges, stressing the tragedy of cultural suspicion and mistrust that besets the relationships between Pakistan and the US, endeavouring to open and facilitate dialogue. Despite utilizing spaces of ambiguity to expose the dangers of binary thinking, both novel and film ultimately demonstrate that representations are still unable to escape the loop of orientalism and re-orientalism, highlighting the tension of how East and West continue as locked into this circular mode of relational identity.
\end{abstract}

\title{
Introduction
}

Globetrotting between modern-day Lahore, the Philippines, Chile and New York, Mohsin Hamid's novel The Reluctant Fundamentalist (2007) traces the radicalization of a Pakistani protagonist with whom the reader is invited to identify. New York-based filmmaker Mira Nair read the novel in manuscript and decided to adapt it. The film adaptation was released five years after the novel was first published. Feeding a need to understand the transnational lieu de mémoire that 9/11 has become (Erll, 2008: 2), a different approach to 9/11 was purposely developed in the film, such that the present of the diegesis was located a decade after the tragic event, and the dimension of the plot geographically expanding to Istanbul. 
This meant reflecting the socio-historical upheavals in Pakistan after the novel's publication, as the screenwriter and producer Ami Boghani notes: "Mira tasked the writing team with keeping the film utterly contemporary yet resoundingly timeless and so, as the landscape of Pakistan changed, [the] screenplay evolved alongside it" (Nair et al., 2013: 21). Nair wished to capture the continuously evolving relationship between Pakistan and the US, and this involved rethinking that relationship as originally portrayed in the novel. Hamid's representation of Pakistan coexists with that of "America," the US's mythic selfrepresentation as both a location of utopia (symbolizing opportunity and hope) and dystopia (Bercovich, 1993: n.p.). The seven years it took Hamid to write The Reluctant Fundamentalist, in the context of counter-terrorism politics brought about by a global War on Terror (Neal, 2010: n.p.), gave him time to cultivate a specific representational stance towards the relationship between America and Pakistan. Changez, Hamid's narratorprotagonist, rebels over what he sees as America's repeated self-serving interventions in Asia: "in each of the major conflicts and standoffs that ringed my mother continent of Asia, America played a central role" (Hamid, 2007: 156). The epiphany that prompts his return from Chile to New York and later to Lahore is motivated by his witnessing of the noninterventionist American response to the 2001 Indian Parliament attack: he realizes his country is again being used as a pawn.

The US and Pakistan are not only changing geopolitical entities, but are also imagined geographies. In the case of America, as Jean Baudrillard observed, it is on a "fictive basis that it dominates the world" (1989: 29). Just as the character of the American in Hamid's novel the diegetically addressed "you," often a direct address to the reader — seems to be left with no choice but to accept Changez as interlocutor, the narrator-protagonist has apparently inveigled a place for himself by monopolizing the script, presenting himself as our spokesman not just for Pakistan, but also, audaciously, for America. Yet, this forcefulness on the narrator's part is deceptive, as readers are tasked with critical awareness. Hamid has made it clear in interviews and through his repeated use of the second-person mode of address that he wishes (almost demands) readers to play an active role in the reading contract and use their imaginations.

Against such backdrop, this article attempts a comparative study of The Reluctant Fundamentalist and its cinematic adaptation - two transcultural texts which deal differently with the US's shifting foreign policy and public perception towards Pakistanand vice-versa. By juxtaposing these texts, we assess the ways in which the formerly (and to large extent, continuing) orientalist relationship between Pakistan and the US is recast and, in some 
instances, re-orientalized by Hamid and Nair. This article begins by examining the transgressive nature of the novel, juxtaposed with the bridging efforts of the film adaptation. We contend that the main departure from novel to adaptation is that it was Nair's reiterated directorial intent, in various interviews, that her film be viewed as an opening of the channels of interpersonal communication, rather than a confrontation. This departure gives rise to questions of how the ambivalence and provocativeness of the "source" text translates into the film adaptation, and the extent to which the film format makes the narrative more palatable and appealing to wider audiences as compared to the novel's target readership. This article does not argue for the fidelity of film script to novel when considering its cinematic afterlife. Instead, it notes how Nair's film adaptation proposes a counter history to post-9/11 Islamophobia, and the limited extent to which this conciliatory stance, as well as the novel's confrontational stance, works.

\section{Setting the scene: confrontation and conciliation}

In the 1970s, Edward Said highlighted how the East had long been represented and spoken for by the West, and how the East's identity has therefore been in part imagined and constructed by the West relationally to its own identity. Re-orientalism theory (Lau, 2009) notes that the East (in particular South Asia) has now seized self-representation to a large degree, yet continues to draw on Western referential points and use Western yardsticks as it attempts to self-define. Moreover and insidiously, whether intentionally or otherwise, contemporary re-orientalizing, Eastern representations continue to be Western-centric: maintaining the status quo of the original orientalist dichotomy, reinforcing the centrality of the West. However, despite continuing to re-orientalize, writers are able to reclaim the functional and discursive value of the commonly marketed exoticisms, such as the Muslim other as terrorist. Re-orientalism theory examines the impact of these subversive discursive strategies in terms of identity negotiations, investigating how "cultural producers with eastern affiliations come to terms with an orientalized East, whether by complying with perceived expectations of Western readers, by playing (along) with them or by discarding them altogether" (Lau and Mendes, 2011: 1). By foregrounding continuing and changing configurations of power and spheres of influence, re-orientalism allows for a more situated analysis of how models of belonging have been radically changing through the claim for rights for new identities and platforms of self-representation. 
Informed by the post-9/11 distrust of the Muslim other, Hamid's novel, published six years after the World Trade Centre attacks in 2007, assumes a confrontational stance. This represents a new way of addressing the English-reading audience, mostly Western-based, confronting processes of othering within Western identity constructions which underscore difference and reinforce damaging stereotypes about potential terrorists. This stance constitutes a 180-degree turnaround from a former postcolonial pattern of South Asian authors creating and sustaining an exotic register for the Western reader, fiction that "goes out of its way to avoid creating any sense of discomfort or awareness of historical complicity in its Western audience" (Shivani, 2006: 3). The Reluctant Fundamentalist challenges its readership, forcing the awareness of historical complicity that Shivani finds absent in other writings, engaging in a discomfiting "reverse racial profiling" (Banita, 2010: 243) wherein it is the racial other who engages in profiling back. Works by Hamid, as well as by Aravind Adiga and Indra Sinha (to mention two other examples), offer a nakedly confrontational stance in their deliberately crude narratives, which are at times even accusatory and offensive. Hamid's The Reluctant Fundamentalist is exemplary in this respect: the writing is menacing and sinister, dependent upon an unreliable narrator whose voice dominates, and it holds its cards close to its chest instead of treating the reader as a confidant.

Hamid spent part of his early childhood in California, worked for a decade in New York and London, and now divides his time between Pakistan, America, Italy and Greece. As he wrote in an article for The Guardian (2014: n.p.), “[m]y life has come full circle, geographically speaking. Twice." Without intending to conflate author and protagonist of The Reluctant Fundamentalist, Changez, like Hamid, was also Lahore-born and raised, and Princetoneducated. In an interview with Michelle Blankenship at the time of publication, Hamid drew parallels between the geography of Changez's world and his own (Blankenship, 2007: n.p.), stressing the gulf between the two — his and the protagonist's early love affairs with America notwithstanding. However, in a later interview after the film's release, he emphasized a profound difference between them: Changez "feels he has to pick one or the other - Pakistan or America," whereas Hamid does not "want to pick sides," but rather embraces "American and Pakistani, all mixed up" (McCartney, 2013: n.p.). It would seem that, although this novel has been identified as a "fundamentally anti-America novel" (Face to Face, n.d.: n.p.), Hamid's position is more nuanced than that of his protagonist:

I feel I have written from a stance that is both critical of and loving toward America. I hope that readers will feel my affection and see that my intent is not to gloss over the 
very real pain of September 11 but rather to reconnect parts of my world, and myself, that have grown increasingly divided. (Blankenship, 2007: n.p.)

There is a note of disclaimer in Hamid's earnest, defensive explanation - a mollifying tone notably absent in the novel, which is determinedly non-placatory. The mention of reconnection and the acknowledgement of "pain" seem to be Hamid's effort to keep the channels of communication open, in direct contrast to the pleasure Changez experiences watching the 9/11 attack on TV: "Yes, despicable as it may sound, my initial reaction was to be remarkably pleased [...] I was caught up in the symbolism of it all, the fact that someone had so visibly brought America to her knees" (Hamid, 2007: 73). ${ }^{1}$ A few years after the Blankenship interview, a more confrontational stance is found in, for example, Hamid's texts on drone warfare in Pakistan. ${ }^{2}$ His "largely American-educated self is profoundly disappointed by America," he confesses, "partly because the US's bellicose excesses in foreign policy become more visible the closer you are to where American bombs are hitting the ground" (Hamid, 2014: n.p.).

The Reluctant Fundamentalist grabbed literary attention with its deployment of the lesscommon, Camus-inspired, dramatic monologue style (Ilott, 2013; Morey, 2011), which, as critics swiftly noted, permits no other voices (Munos, 2012: 400). From the outset, Nair distanced herself from the novel's style: "The book is a monologue of a Pakistani man talking to an American who doesn't say a word [...] That's not going to sell any tickets. I'm just joking, but that's not a movie" (McDowell, 2012: n.p.). Nair's recasting of the novel's monologic form into a dialogue set the aim of bridging the East-West divide. She attempted to counterbalance Changez's menacing tone in the novel, driven by a desire to foster the audience's empathy for the Muslim protagonist of a 9/11-centred plot, moving it "out of the hot-blooded political debate and into the emotional, human dimension," as Hamid put it (Nair et al., 2013: 35).

Although the adaptation follows the novel's second-person narrative relatively closely, perhaps its most significant departure is Nair's decision to base the film on a dialogue as opposed to Hamid's distinctive monologue. This is not a mere stylistic or technique difference, but a required step to move it away from the novel's aggressive tone without losing the menace of the plot. As Hamid noted, "The effect I was reaching for [...] is that you're in a theatre and there's one actor on the stage taking you through the play" (Kaplan, 2013: n.p.). This leads to the monologue style, addressed to an unnamed and voiceless American (Munos, 2012: 400), who can be interpreted as a stand-in for the (Western) target reader. This narrative technique provides the reader with Changez's perspective, preventing 
him or her from hearing or seeing the American's perspective, and thus "refusing the normalizing consolation of a dialogue" (Morey, 2011: 139). From the outset, the Pakistani "voice" is dominant.

Not only does this dramatic monologue style hog the speaking platform, it also contains two “tricks," as Peter Morey points out (2011: 136-9). Firstly, the novel is "falsely polyphonic: we "hear" the voices of Erica, Jim, Wainwright and others, but they are all ventriloquized by Changez"; and secondly, the confessional form is not an actual disclosure or divulgence, no "true confession of former radicals"; rather, it is designed to create an atmosphere of greater confidence and confidentiality, resulting in the "novel-as-hoax" (ibid). The novel, with respect to the needs of a Western audience, points out that the Pakistani narrator must tread a very fine line when self-revealing, or confessing, because, "[t]he confession that implicates its audience is - as we say in cricket - a devilishly difficult ball to play. Reject it and you slight the confessor; accept it and you admit your own guilt" (Hamid, 2007: 70). The confessional form leaves Hamid with this difficult ball to play: not wanting to alienate the audience, while all but needing to do precisely that to perform his otherness.

Changez's tone is all-important in Hamid's representation of the Pakistani perspective, which is defensive and wronged. Claudia Perner writes of the "over-polite narrative voice" (2011: 29), and Delphine Munos claims that it is increasingly bitter and accusing (2012: 400). Hamid has commented on this in numerous interviews, acknowledging that Changez speaks in a strange accent: "an oddly anachronistic, almost British-sounding but yet undeniably Pakistani form" (Yaqin, 2008: 46). His protagonist's voice is "quasi-Victorian, elite, private schooling" and has "a strange quixotic element in English and Urdu" (Singh, 2010: 154 155), rooted in the Anglo-Indian heritage of elite Pakistani schools and its accompanying historical pride and particular value system. As the protagonist confides to the American early in the novel, "like Pakistan, America is, after all, a former English colony, and it stands to reason, therefore, that an Anglicized accent may in your country continue to be associated with wealth and power, just as it is in mine" (Hamid, 2007: 42). Changez's speaking style is thus designed to resonate with several axes of power: former colonial mastery, class, and Western education and/or association.

It is important to stress that Changez himself is of an elite class within Pakistan. Although his family had lost some influence by his generation, his educational background and social status place him in the exclusive upper classes, within the context of a tremendously stratified society. Part of the tension or ambiguity of his self-identity, particularly in the US, derives from not being able to transfer much of the currency of his elite status to the West (though his 
refined manners and speech do lend him some social capital). It is also likely that Changez may identify more easily with his social class internationally than with his countrymen from the working classes; although he speaks as a Pakistani, he does not necessary speak for Pakistanis. It is important to note that both Hamid and Nair elected an upper-class protagonist, Western-trained and Western-educated, to represent the Pakistani perspective. This, too, is typically re-orientalist: while the power of representation may have reverted to the Orient, representation nevertheless continues to be manipulated by a very small elite, and cumulatively by those with very strong Western connections. Changez's re-orientalism is hence tempered by the dual positionality of oppressed and oppressor: as the formerly colonised and a member of the Global South, but also as a part of the elite in a highly hierarchical society.

Hamid also acknowledges that Changez's excessive politeness is designed to be menacing, but more than that, its "courtly anachronism and formality" plays to received ideas about Islam in mainstream Western culture (Singh, 2010: 154-155). The novelist tells us that the formal rigidity, potential menace and sense of hailing from the past of Changez's distinctive language "chimed stylistically with certain popular stereotypes about Muslims and Islam" (Hamid, 2011: n.p.), which sounds like Hamid was playing to the gallery. It is interesting that, elsewhere in the interview, Hamid refers to this over-politeness as "false politeness" (Yaqin, 2008: 46), which is subtly different from being overly formal or over-polite, but in keeping with the authorial intention to deliberately play up to perceptions of certain mainstream Western clichés and stereotypes of others. Hamid almost wishes to exploit this weakness of the mainstream readership, or at least expose its shortcomings.

Morey points out that an unavoidable theme running through the novel is that Changez is always acting roles - acting like an American, or a poor-boy-made-good, or an exotic acquaintance - because "he lives with the knowledge that his identity is constructed in the gaze of others" (Morey, 2011: 144). Changez's distinctive voice, with its cultural connotations of an upper-class background, is a re-orientalist voice, the voice of a character who has been Western-educated and is now performing an identity for a Western audience. It is not a wholly false or insincere enactment, but is made angrily and indignantly at being in a position of an exhibit, a spectacle. Attention is drawn to the stylization of his form, designed so that the reader is unable to forget the framework. The voice of the novel continuously channels performative impersonation, as if Pakistanis in the US are always compelled to act because they are constantly aware of being viewed through Western lenses and interpreted by the West via orientalist scrutiny, always othered. Hamid tells us clearly that this novel not 
only attempts to look at America to return the scrutiny, but does so with "still stubbornly Pakistani eyes, or eyes that reflected the place that I came from" (Yaqin, 2008: 45), to boldly "gaze back" at America, particularly from the platform of Changez's relatively privileged position as a member of Pakistani elite with access to Western education. Could Hamid be implying that, like Changez who performs for an American audience, a skewed representation of Pakistan is being performed for the West (one that abides by the geopolitical agenda of the West, turning the country once again into a pawn), and that the novelist himself is writing for the eyes of Western readers? Might he be suggesting that reorientalism is in part a consequence of the expectation(s) of target audiences?

In contrast to the film's bridging of the gulf between the two worlds, Pakistan and the US, the novel represents them to be - in the long run, and despite initial amicabilities unbridgeable. Changez, in the opening words of the novel, as per the leitmotif of South Asians as "authentic insiders" (a spin on the figure of the "native informant") and cultural “emissaries" (Narayan, 1997: 142), introduces himself to the American as a guide and bridge between their cultures. In a tongue-in-cheek manner, Changez offers help with a fine flourish, while simultaneously sweeping aside the American's wish for disguise or secrecy. In fact, from the outset the American is the one identified as potentially threatening, "more than looking" somewhat sinister, while establishing Changez's credentials as a "lover of America" (Hamid, 2007: 1). Later, this is seen to be disingenuous, given the protagonist's future disillusionment with America and abandonment of it, in accordance with the conventions of the Bildungsroman.

However, Hamid is counting on the fact that the Western reader will accept such a narrator as Changez to guide them through a largely unfamiliar Pakistani culture. Hamid, understanding the burgeoning post-9/11 interest in South Asian literature in English, utilizes and subverts it, underlining the dangerous situation of orientalism's asymmetrical knowledge, where the other is well informed about the self, while the centre knows relatively little about the periphery. In the novel, he brandishes his detailed knowledge of New York City: "I emerged from the 6 train onto Seventy-Seventh Street, in the heart of the Upper East Side. The area [...] felt surprisingly familiar, although I had never been there before; I realized later that I owed my sense of familiarity to the many films that had used it as a setting" (Hamid, 2007: 48-49), showing that while America is familiar to non-Americans and Pakistanis, Pakistan is largely foreign terrain, in many ways, and extremely unfamiliar to Americans. This furnishes parallels between Changez and the American, whereby the former is conversant with both 
America and Pakistan, while the American is very uncomfortable and out of place in Pakistan, his ignorance his key vulnerability.

In Changez, Hamid presents a protagonist who subverts orientalism, but while he-attempts to seize voice and representation from the West about the West, the representation of Pakistan in the novel remains troublingly orientalist. Hamid is showing Americans (and the West at large) America through the eyes of those who may have reason to perceive themselves as wronged and duped by America, the janissaries ${ }^{3}$ disillusioned. As such, the narrative is full of menace and imminent danger, tensed and loaded with the threat of violence. For a novel where nothing actually happens except for a meal, a conversation, and a walk back to the hotel, the undercurrents of menace are curiously strong. Much of that is suggested through the strange stillness of the significant lack of "action." but of course, much is conveyed through the crucial tone and voice of the narrator. This, then, challenges the film to find a way to deliver the same sense of barely restrained menace without making it overt.

Nair's stated intention was to direct a "human thriller" (Nair et al., 2007: xii). She recognized a thriller element in Hamid's novel in its play with ambiguity; nonetheless, she argued, "this sort of ambiguity would not work neatly in a film" (Nair et al., 2007: 11). Suspense is created from the start with a scene in Lahore (actually shot in the Muslim neighbourhoods of Old Delhi). The first seven minutes show the abduction of Anse Rainier, a North American professor and colleague of Changez at Lahore University, intercut with the qawwali Kangna, performed by Fareed Ayaz and Abu Muhammad (celebrated Pakistani Sufi performers) who perform in a cameo. For the shots in this opening sequence, as well as in the rest of the film, the camera is handheld or suspended on a bungee cord. This option was devised to add to the tense atmosphere, as Nair recounts: "throughout the shooting I kept on feeding him [the singer Fareed Ayaz] more paan, because the red of the paan was going to evoke the blood of the kidnapping and we - quite literally, since the camera was on a bungee - would enter his mouth at certain moments of the performance" (Nair et al., 2007: 134).

Nair and LA-based screenwriter William Wheeler fleshed out the character of Bobby Lincoln, an American journalist (who is also working undercover for the CIA), out of the unnamed American in Hamid's novel. In Nair's words, “the encounter between the characters of Changez and Bobby mirrors the mutual suspicion with which America and Pakistan (or the Muslim world) look at one another" (Nair et al., 2007: xi). The film audience cannot tell exactly the intentions behind Changez's need to narrate the story of his shifting loyalties to this journalist. During the interview with Lincoln in a Lahore teahouse, he is vociferous in his criticism of American intervention, particularly of US presence in Pakistan, and this leaves us 
unsure of what the outcome of this meeting might be. "In my film," Nair revealed in an interview with the New York Times, "we use the enigma of the situation — is he a spy, is he a terrorist, are neither, are both? - as the springboard for a dialogue, a bridge connecting them, and connecting us, making each of us see ourselves in what we had regarded as 'the other"” (Kaplan, 2013: n.p.). Against expectations fostered and amplified by the protagonist's ambiguous demeanour and his reputed links to Islamists, the viewer finds, in the third act added by Nair, that he is not a terrorist. This third act — in Hamid's phrasing, "the first significant departure from my novel" (Nair et al., 2007: 23) — offers a resolution to the undercurrent of threat. While the beginning frames the cinematic narrative in ambiguity and the play on mutual suspicion is sustained throughout, the ending provides a tacit denouncement of the injustices resulting from racial and religious profiling through a terrible cultural misunderstanding when a student of Changez is tragically shot dead.

\section{Spaces of ambiguity}

Two spaces of ambiguity can be flagged in The Reluctant Fundamentalist and its film adaptation. The first is within the storyline, particularly its nebulous ending, which in turn throws doubt upon the rest of the story preceding it, and renders doubtful Changez's motives, impacting the narrative's trustworthiness. In addition, both novel and film create a new space of ambiguity where the relationship between Pakistan and America, East and West, are concerned. Both the novel and its adaptation succeed in exposing the inflated rhetoric associated with terrorism and in drawing the viewer's attention to the hypocrisy of the antiMuslim profiling that ensued in the wake of 9/11.

It is important to note that both Hamid and Nair, although the former set out to challenge and the latter to build bridges across Western insularity, chose an upper-class protagonist to represent the Pakistani perspective, and stressed his highly cultured background. One of Nair's reasons for adapting Hamid's story for the screen was to showcase Pakistan's rich artistic expressions, "revealing Pakistan in a way that one never sees it in the newspapers, with its extraordinary refinement" (Nair et al., 2013: xii; emphasis added). By her own admission, instead of merely articulating Pakistan as an actor in the global War on Terror, she:

looked for a tale to tell of contemporary Pakistan, a tale one never sees [...] [she] wanted to make a contemporary film about Pakistan, one that would break all misconceptions about the country and reveal it in a manner not seen before - as a 
simmering, confident nation caught between its ancient heritage and the demands of a globalized world. (Nair et al., 2013: 11)

To curb damaging stereotypes, the filmmaker intended to display the various cultural achievements (in opposition to the difficulties) of a nation known to many in the West through processes of othering in many sections of the mainstream media. Her Pakistan is a place vivified by "the searing poetry of Faiz, its heart-stopping Sufi music and ancient culture that is confident in fashion, painting and performance" (Nair et al., 2013: xii), not just Islamic extremism and the terrorism that often accompanies it.

An important part of Nair's determination to confront the orientalist metanarrative of Pakistanis-as-terrorists is indeed the film's emphasis on showcasing the "high culture" of Pakistan, for example through the reinforcement of a literary connection in the plot. While in the novel Changez's great-uncle was a poet, famous in the Punjab (Hamid, 2007: 142), in the film his father is the poet, "steeped in the traditions of rich Lahori culture," hence Riz Ahmed's use of traditional, literary Urdu from the outset; as Nair notes, "Changez's parents embody the elegance and soul of upper-middle-class contemporary Lahoris" (Nair et al., 2013: 58). Though certainly laudable, Nair's reliance on the "high culture" of Pakistan one inextricably associated with upper-middle-class identity — as a platform to redeem the country in the eyes of a Western audience might be seen as one of the less radical aspects of the adaptation. While engaging in a conscious effort to translate it for those presumably otherwise alienated audiences, the film gestures towards what Uma Narayan calls a "cultural riches" approach on Nair's part, one that Narayan critiques as "often tend[ing] to be inattentive to the material, social, and political contexts in which these achievements were embedded" (Narayan, 1997: 128-129).

Hamid's novel draws attention to the fact that elite Pakistanis have always been forced to look at themselves with the uncomfortable awareness of first being seen through the eyes of another culture, and subsequently always having to correct for this (mis)translation. So, although Hamid stubbornly insists on looking through Pakistani eyes, he is aware he nevertheless looks through an American lens, and calling attention to the artifice of the lens is his way of countering this. In the novel, Changez reflects on precisely this point:

There are adjustments one must make if one comes here from America; a different way of observing is required. I recall the Americanness of my own gaze when I return to Lahore $[\ldots]$

But as I reacclimatized and my surroundings once again became familiar; it occurred to me that the house had not changed in my absence. I had changed; I was 
looking about me with the eyes of a foreigner, and not just any foreigner, but that particular type of entitled and unsympathetic American who so annoyed me when I encountered him in the classrooms and workplaces of your country's elite. This realization angered me; staring at my reflection in the speckled glass of my bathroom mirror I resolved to exorcise the unwelcome sensibility by which I had become possessed. (Hamid, 2007: 124)

It is noteworthy that the narrator is "angered" by having learnt to look through an American lens, and wishes to "exorcise" himself of this sensibility, almost as if he needs to rid himself of a demon. As already mentioned, cultural currency often does not translate well across different social contexts, particularly from East to West; in part because of Changez's privileged background, he feels the insult even more keenly when he catches himself having allowed himself to be brainwashed and unwittingly taking on orientalist stances, because it is a negation of his identity and thus a further offense to his pride.

Hamid wants readers to feel the unease between the Pakistani protagonist and the silent American addressee, which echoes and/or parallels the tension of mutual suspicion between America and much of the Muslim world: "I decided on a frame that allowed two points of view, two perspectives, to exist with only one narrator, thereby creating a double mirror for the mutual societal suspicion with which Pakistan views America and America views Pakistan. Those two decisions unlocked the potential of the novel" (Hamid, 2011: n.p.). The final version of the novel arrives at what the writer says he hoped was:

an appropriately permeable form, a dramatic monologue, a half-conversation spoken to "you" that leaves it to the reader to supply its missing context. So readers end up creating their own versions of what happens in the book, and the book in turn moves and shifts and reflects in response to the individual inclinations and world views of readers. (Hamid, 2011: n.p.)

Two years before the adaptation's release, Hamid spoke as follows on media-specific strategies that contribute to the difference between novels and films or television programs: "The Reluctant Fundamentalist is read differently by different readers, and so that's why I think it's a rich space. And it's something that I think that fiction has a unique power to engage in. Unlike a film or a television program, where the acting is done for you, in a novel we are just seeing visual characters" (Singh, 2010: 156). The novel's deliberately inconclusive ending which refuses linearity, is characterized by a cyclical pattern, moving back and forth from the present to the past. In contrast, the adaptation offers a resolution to Hamid's cyclical plot. The tragic (and possibly uncomfortable) conclusion provides the 
audience with a Kermodian sense of an ending (Kermode, 1967). The desire for an ending is defeated in the novel by its non-linear structure (urging the reader to create an ending of their own), whereas the adaptation wholly satisfies this need.

The deliberately open-ended ambiguity of the novel has of course been the topic of much discussion (Yaqin, 2010; Morey, 2011; Chambers, 2011; Perner, 2011; Gamal, 2013; Ilott, 2013) and it would seem that to cause further questioning, and to leave the reader with disquiet and discomfort regarding the never-ending pattern of suspicion in how East and West view one another, is precisely Hamid's intention. The medium of the film cannot be expected to leave quite as much to the imagination of the readers as the book, given the need to translate from the textual to the visual medium. Noting the differences in media, Hamid reminds us that the "film is inspired by the novel, but it isn't the novel on screen" (Nair et al., 2007: 23). The adaptation's "failure" to sustain the novel's deliberate ambiguity beyond the last scene is intentional and perhaps unavoidable - conventionally, films tend to be more closure-oriented. Besides, all adaptations might be seen as potential failures if we impose a criterion of fidelity to the texts and, most importantly, the contexts of emergence and reception of these different texts must be taken into account. Hamid's reminder offers a way out of the bind of presuming the inherent superiority of the "source" or "original" text and of regarding the adaptation as a belated version of that text.

\section{Conclusion}

Our interconnected world no longer affords a single metanarrative of the past, nor, for that matter, accepts stable shared national memories. Individuals, communities and nations, and even regions selectively engage in strategic affiliations, claiming and prioritising connections, while denying or obscuring others. Instead of a monologue, Nair aimed at a dialogue about the tragic events by showing both sides. Instead of contributing towards stabilizing the cultural memory of $9 / 11$, she wants her film to destabilize these memories, to act as an instance of counter-memorializing through a focus on the other of these memories. In her own words, "I always want to answer the question, 'Who is the other?' and make that 'other' palpable [...] And in light of the kind of danger we live in, it's about time we start knowing each other" (Chen, 2013: n.p.). By enabling us to think of 9/11 as a culturally- and racially-encoded event, the adaptation challenges the seemingly unruffled facade of the memorializing of a collective (as in North American) trauma nurtured by earlier Hollywood productions. Additionally, it forces a welcome displacement of trauma narratives (and their 
analysis) associated with 9/11 away from the Euro-American contexts. Cathy Caruth noted the transcultural aspect of trauma in catastrophic ages, wherein "trauma itself may provide the very link between cultures" (Caruth, 1995: 11), an aspect underscored by Nair's memories of the harrowing events of 2001:

It took me a week to get back there and, when I did, the whole place reminded me of images from my home country - the refugee camps, the sense of a war zone, the sense of fear. In New York you rarely hear anyone speaking English. Everyone is a foreigner and yet everyone belongs. But suddenly it became a place where everyone who looked like us was viewed as "the other." It was a deeply disturbing time — both for us and for the world. (Brooks, 2012: n.p.)

Issues of cultural foreignness/familiarity and the implied construction of an audience are of particular relevance to the film version of The Reluctant Fundamentalist. Although Nair had good reasons for changing the original stance of the book, and perceiving there was more to be gained by conciliation than confrontation particularly in the second decade of the millennium and its changed political landscape, there are nevertheless problems with some of her basic premises. Taking up a role of facilitator in the dialogue between cultures, Nair aims to destabilize the conservative discourse of the "clash of civilizations" (Huntington, 1996). The film mirrors the shift from a monolithic US foreign policy and public perception towards Pakistan (and vice versa) after the September 11 attacks into a more fluid and negotiable status ten years later. However, despite the conciliatory approach of the adaptation, making an alternative reading of the novel possible, the film ultimately does not deliver the reorientalist subversion of neo-imperialist dominance for which the novel was celebrated. That said, to some extent the novel is also not entirely successful in its re-orientalist subversion, unable to depart from the East-West binary trapped in processes of self-othering and Western-centring. Both film and novel depict Pakistan and America as oppositional, with seemingly mutually exclusive identities and affiliations. These literary and filmic representations are located within a socio-political structure where the Pakistani is perpetually posited as the hostile other in an orientalist way, not just by the American (the West), but also by the protagonist himself (the East). This continued self-peripheralizing of the East/Orient is characteristic of re-orientalism. The narrative of The Reluctant Fundamentalist appears to imply a continuous "loop," where Western modernity is still reliant on orientalizing the East, which in turn is dependent on reacting against or responding to Western perceptions to define even its modernising self. 
Note: We would like to thank the anonymous reviewers for their suggestions and comments.

\section{Works Cited}

Banita G (2010) Race, risk, and fiction in the War on Terror: Laila Halaby, Gayle Brandeis, and Michael Cunningham. Lit: Literature Interpretation Theory 21(4): 242-268.

Baudrillard J (1989) America. Trans. Chris Turner. London: Verso.

Bercovich S (1993) The Rites of Assent: Transformations in the Symbolic Construction of America. New York: Routledge.

Blankenship M (2007) Interview with Mohsin Hamid. Media Enquiries. Available at: http://www.harcourtbooks.com/reluctant_fundamentalist/interview.asp (accessed 30 May 2014).

Brooks X (2012) Venice Film Festival opens with 9/11 drama The Reluctant Fundamentalist. The Guardian 29 August. Available at: http://www.theguardian.com/film/2012/aug/29/venicve-film-festival-reluctant-fundamentalist (accessed 9 September 2014).

Caruth C (1995) Trauma and experience: introduction. In: Caruth C (ed) Trauma: Explorations in Memory. Baltimore: Johns Hopkins University Press, pp. 3-12.

Chambers, C (2011) A comparative approach to Pakistani fiction in English. Journal of Postcolonial Writing 47(2): 122-134.

Chen J (2013) Mira Nair's The Reluctant Fundamentalist is a true conversation piece. Hyphen 16 May. Available at: http://www.hyphenmagazine.com/blog/archive/2013/05/miranair\%E2\%80\%99s-reluctant-fundamentalist-true-conversation-piece (accessed 9 September 2014).

Erll A (2008) Cultural memories studies: an introduction. In: Erll A and Nünning A (eds) Cultural Memory Studies: An International and Interdisciplinary Handbook. Berlin: de Gruyter, pp. 1-18. 
Face to Face Intercultural ABN (n.d.). Available at: http://www.facetofaceintercultural.com.au/the-reluctant-fundamentalist (accessed 30 May 2014).

Gamal, A (2013) The global and the postcolonial in post-migratory literature. Journal of Postcolonial Writing 49 (5): 596-608.

Hamid M (n.d.) Mohsin Hamid talks about The Reluctant Fundamentalist. Available at: http://www.penguin.com.au/lookinside/other/9780241143704/Interview.pdf (accessed 30 May 2014).

Hamid M (2007) The Reluctant Fundamentalist. London: Hamish Hamilton-Penguin.

Hamid M (2011) Mohsin Hamid on writing The Reluctant Fundamentalist. The Guardian Book Club 14 May. Available at: http://www.theguardian.com/books/2011/may/14/mohsinhamid-reluctant-fundamentalist-bookclub (accessed 9 September 2014).

Hamid M (2014) Why migration is a fundamental human right. The Guardian 21 November. Available at: http://www.theguardian.com/books/2014/nov/21/mohsin-hamid-why-migrationis-a-fundamental-human-right (accessed 21 November 2014).

Huntington S (1996) The Clash of Civilizations and the Remaking of World Order. New York: Simon \& Schuster.

Ilott S (2013) Generic frameworks and active readership in The Reluctant Fundamentalist. Journal of Postcolonial Writing 50(5): 1-13.

Kaplan F (2013) Crossing dangerous borders: Mira Nair on The Reluctant Fundamentalist. The New York Times 19 April. Available at: http://www.nytimes.com/2013/04/21/movies/mira-nair-on-the-reluctantfundamentalist.html?_r=0 (accessed 9 September 2014).

Kermode, F (1967) The Sense of an Ending: Studies in the Theory of Fiction. New York: Oxford University Press.

Lau L (2009) Re-Orientalism: the Perpetration and Development of Orientalism by Orientals. Modern Asian Studies 43(2): 571-590. 
Lau L and Mendes AC (2011) Re-Orientalism: a new manifestation of Orientalism. In: Lau L and Mendes AC (eds) Re-Orientalism and South Asian Identity Politics: The Oriental Other Within. London and New York: Routledge, pp. 3-16.

McCartney J (2013) The Reluctant Fundamentalist. The Telegraph 12 May. Available at: http:/www.telegraph.co.uk/culture/film/filmreviews/10044349/The-Reluctant-

Fundamentalist.html (accessed 9 September 2014).

McDowell A (2012) Five things we learned at the press conference for The Reluctant Fundamentalist. National Post Sember 9. Available at: http://arts.nationalpost.com/2012/09/09/five-things-we-learned-at-the-press-conference-forthe-reluctant-fundamentalist/ (accessed 9 September 2014).

Morey P (2011) 'The rules of the game have changed': Mohsin Hamid's The Reluctant Fundamentalist and post-9/11 fiction. Journal of Postcolonial Writing 47(2): 135-146.

Munos D (2012) Possessed by whiteness: interracial affiliations and racial melancholia in Mohsin Hamid's The Reluctant Fundamentalist. Journal of Postcolonial Writing 48(4): 396405 .

Nair M et al. (2013) The Reluctant Fundamentalist: From Book to Film. New Delhi: Penguin Studio.

Narayan U (1997) Dislocating Cultures: Identities, Traditions, and Third World Feminism. New York: Routledge.

Neal A (2010) Exceptionalism and the Politics of Counter-terrorism: Liberty, Security and the War on Terror. London: Routledge.

Padmanabhan D (2013) Mira Nair's post-9/11 film: a conversation with 'the other side'. 10 May. Available at: http://asiasociety.org/india/mira-nairs-post-911-film-conversation-otherside (accessed 9 September 2014).

Perner C (2011) Tracing the fundamentalist in Mohsin Hamid's Moth Smoke and The Reluctant Fundamentalist. ARIEL: A Review of International English Literature 41(3-4): 2331.

Shivani, Anis. (2006) Indo-Anglian fiction: the new Orientalism. Race and Class 47(4): 125. 
Singh H (2010) Deconstructing the terror: interview with Mohsin Hamid on The Reluctant Fundamentalist (2007). ARIEL: A Review of International English Literature 42(2): 149156.

Yaqin, A (2008) Mohsin Hamid in Conversation. Wasafiri 23(2): 44-9.

\footnotetext{
${ }^{1}$ This echoes Hamid's eyewitness account of "white people" smiling as the first tower collapsed on TV; it "was the symbolism of the act that pleased them" was his explanation (McCartney, 2013: n.p.).

${ }^{2}$ An example is the short story "Terminator: Attack of the Drone," published in The Guardian Review Book of Short Stories (2011).

${ }^{3}$ Janissaries were Christian boys captured by the Ottomans and trained to be soldiers in a Muslim army, known for their ferocity and loyalty. These janissaries fought to erase their own civilisations. Changez saw himself as a modern-day janissary, "a servant of the American empire at a time when it was invading a country with a kinship to mine and was perhaps even colluding to ensure that my own country faced the threat of war" (Hamid, 2007: 152).
} 